\title{
ANALISIS KEBUTUHAN PENGEMBANGAN ANGKUTAN KHUSUS KARYAWAN PADA PUSAT PEMERINTAHAN KOTA DENPASAR DI LUMINTANG
}

\author{
Ni Pt. Emmy Oktariani ${ }^{1}$, P. Alit Suthanaya ${ }^{2}$, I G. Putu Suparsa, ${ }^{2}$
}

\begin{abstract}
Abstrak: Angkutan khusus karyawan merupakan suatu penerapan manajemen lalu lintas dengan meniru carpooling sehingga mampu mengurangi penggunaan kendaraan pribadi yang digunakan untuk menuju pusat kegiatan dengan satu armada angkutan khusus karyawan. Tujuan dari penelitian ini untuk menganalisis karakteristik sosial ekonomi, sistem operasional angkutan khusus karyawan, biaya operasional kendaraan dan penghematannya. Penelitian ini dilakukan pada kawasan Lumintang Denpasar. Metode pengumpulan data dengan menggunakan kuesioner dan wawancara pada pihak-pihak terkait. Dari hasil analisis yang telah dilakukan, diperoleh bahwa sebagian besar $(88,47 \%)$ karyawan menggunakan sepeda motor ke kantor dengan jarak perjalanan terbanyak $5 \mathrm{~km}$, diperoleh 4 rencana trayek angkutan khusus karyawan dengan waktu siklus antara $23 \mathrm{~s} / \mathrm{d} 58$ menit, headway antara $2 \mathrm{~s} / \mathrm{d} 10$ menit dan biaya operasional kendaraan angkutan khusus karyawan setiap harinya antara Rp.252.531 s/d Rp.270.241. Penghematan biaya operasional kendaraan sebesar Rp.810.332.019 dan penghematan bahan bakar sebanyak 6.624 liter per tahunnya.
\end{abstract}

Kata Kunci : Angkutan Khusus Karyawan, Sistem Operasional, Biaya Operasional Kendaraan, Penghematan

\section{THE ANALYSIS OF EMPLOYEE TRANSPORTATION SERVICES FOR DENPASAR CITY GOVERNMENT IN LUMINTANG}

\begin{abstract}
Employee transportation service is one of the traffic management method that imitate carpooling system which can decrease the used of private vehicle that being use towards the centers of activity with employee transportation services. The purpose of this research are to analyze socio - economic characteristic, operational system, vehicle operating cost and cost reduction. This research was conducted in Lumintang Denpasar. The method that was used in this research include field survey such us questionnaire spreading to the respondent and also doing a direct interview to the related parties. Result of the analysis indicated that the majority of employee's $(88,47 \%)$ used motorcycle with average travel distance of $5 \mathrm{~km}$ 's, 4 employee transportation routes were planned with time cycle between 23 to 58 minutes, headway between 2 to 10 minutes and employee transportation operational cost is between Rp.252.531 to Rp.270.241 every day. operational expense saving with total Rp. 8110.332.019 and fuel saving as much as 6.624 liters a year
\end{abstract}

Keywords : Employee Transportation Services, Operational System, Vehicle Operating Cost, Cost Reduction

\footnotetext{
${ }^{1}$ Mahasiswa Program Magister Teknik Sipil, Program Pascasarjana Universitas Udayana

2 Staf Pengajar Program Studi Magister Teknik Sipil, Program Pascasarjana Universitas Udayana
} 


\section{PENDAHULUAN \\ Latar Belakang}

Peningkatan sarana dan prasarana transportasi di Bali yang terus dilakukan, untuk mengimbangi permasalahan transportasi yang terjadi belum memberikan pengaruh yang signifikan bagi permasalahan yang dihadapi. Masih dominannya pengguna kendaraan pribadi yang mendominasi pergerakan transportasi tentunya tidak memberikan pengaruh positif terhadap pembangunan yang telah dilakukan.

Kota Denpasar sebagai Ibu Kota Provinsi Bali merupakan pusat pendidikan, pemerintahan dan perdagangan yang mengalami pertumbuhan penduduk dan laju pertumbuhan ekonomi yang terus meningkat. Sebuah konsekuensi dari perkembangan kota tentunya menimbulkan permasalahan perkotaan khususnya di sektor transportasi. Pusat-pusat pemerintahan yang sering menjadi pusat bangkitan perjalanan menjadi pemicu permasalahan transportasi yaitu menimbulkan kemacetan pada jam-jam tertentu.

Untuk mengatasi hal tersebut diperlukan sarana transportasi yang dapat mengurangi penggunaan kendaraan pribadi karyawan untuk menuju pusat kegiatan. Angkutan khusus karyawan merupakan suatu penerapan manajemen lalu lintas dengan meniru carpooling. Carpooling ini mampu mengurangi penggunaan kendaraan pribadi yang digunakan menuju pusat kegiatan dengan satu armada angkutan khusus karyawan. Potensi penggunaan angkutan khusus karyawan ini sangat perlu dikembangkan, bahkan diharapkan setiap pusat pemerintahan memiliki angkutan khusus karyawan.

\section{Tujuan Penelitian}

Sejalan dengan rumusan masalah yang ada, maka tujuan dari penelitian ini adalah untuk :

1. Untuk menganalisis karakteristik sosial ekonomi dari karyawan, besarnya bangkitan perjalanan serta potensi penggunaan angkutan khusus karyawan pada pusat pemerintahan Kota Denpasar di Lumintang.

2. Untuk menganalisis sistem operasional angkutan khusus karyawan yang dapat diterapkan pada pusat pemerintahan Kota Denpasar di Lumintang.

3. Untuk mengetahui besarnya biaya operasional kendaraan (BOK) untuk pengoperasian angkutan khusus karyawan pada pusat pemerintahan Kota Denpasar di Lumintang.

4. Untuk mengetahui besarnya penghematan biaya operasional kendaraan (BOK) dan penghematan konsumsi BBM dengan dioperasikannya angkutan khusus karyawan.

\section{Batasan Masalah}

Mengingat luasnya cakupan angkutan dalam transportasi maka penelitian ini dibatasi pada aspek-aspek sebagai berikut :

1. Penelitian ini dilakukan pada karyawan SKPD Pemerintah Kota Denpasar yang berlokasi pada kawasan Lumintang Denpasar.

2. Pada penelitian ini tidak melakukan kajian tingkat pelayanan jalan dan simpang di sekitar kawasan Lumintang.

3. Perencanaan sistem operasional angkutan khusus karyawan dilakukan berdasarkan data asal-tujuan karyawan pada saat ini.

4. Bangkitan yang diakibatkan oleh pengunjung/ bukan karyawan pada penelitian ini tidak diperhitungkan.

5. Analisis biaya operasional yang dilakukan tidak memperhitungkan biaya perjalanan (general cost) karyawan untuk menuju halte terdekat.

6. Dalam penelitian ini tidak dilakukan validasi dengan karyawan setempat terhadap usulan trayek yang direncanakan.

7. Saat ini standar untuk angkutan khusus belum ada sehingga digunakan pendekatan standar angkutan umum.

\section{Manfaat Penelitian}

Manfaat yang diharapkan dari penelitian ini antara lain:

1. Bagi mahasiswa, dapat mengetahui, memahami serta menambah wawasan mengenai besarnya bangkitan perjalanan, karakteristik sosial ekonomi karyawan, serta potensi penggunaan angkutan khusus 
karyawan yang dapat diterapkan pada pusat pemerintahan Kota Denpasar di Lumintang.

2. Bagi pemerintah daerah, dapat dijadikan alternatif solusi dalam mengatasi bangkitan perjalanan, penghematan $\mathrm{BOK}$, serta penghematan BBM yang diakibatkan oleh penggunaan kendaraan pribadi yang dilakukan karyawan untuk menuju pusat pemerintahan Kota Denpasar di Lumintang.

3. Bagi perguruan tinggi, diharapkan penelitian ini memperkaya khasanah penelitian di bidang transportasi dalam upaya untuk mengurangi ketergantungan pada penggunaan kendaraan pribadi.

\section{KAJIAN PUSTAKA}

\section{Definisi Angkutan Khusus Karyawan}

Pengertian angkutan berdasarkan pedoman teknis penyelenggaraan angkutan penumpang umum di wilayah perkotaan dalam trayek tetap dan teratur Departemen Perhubungan (2002) adalah pemindahan dan/atau barang dari suatu tempat ke tempat yang lain dengan menggunakan kendaraan. Angkutan khusus karyawan merupakan kendaraan yang dipakai untuk mengantar, baik bekerja maupun pergi untuk kegiatan lain yang tempat dan waktunya sudah ditentukan.

\section{Standar Kualitas Angkutan Umum}

Dalam mengoperasikan kendaraan angkutan penumpang umum, parameter yang menentukan kualitas pelayanan angkutan umum mengacu pada Pedoman Teknis Penyelenggaraan Angkutan Umum di Wilayah Perkotaan Dalam Trayek Tetap dan Teratur, Direktorat Jendral Perhubungan Darat, Departemen Perhubungan tahun 2002 seperti berikut :

1. Waktu tunggu penumpang rata-rata dipemberhentian antara 5-10 menit.

2. Jarak perjalanan menuju angkutan di pusat kota antara 300-500 meter.

3. Frekuensi penumpang yang berganti dalam perjalanan rata-rata $0-1$ kali.

4. Jumlah waktu yang diperlukan dalam perjalanan setiap hari dari / ke tempat tujuan (jam) rata-rata 1-1,5 jam.

5. Headway ideal antara 5-10 menit.

6. Kecepatan berdasarkan kelas jalan.

\section{Trayek dan Rute Angkutan}

Trayek adalah lintasan kendaraan umum untuk pelayanan jasa angkutan orang dengan mobil bus, yang mempunyai asal dan tujuan tetap, lintasan tetap dan jadwal tetap maupun tidak berjadwal. Berdasarkan definisi ini, maka terdapat perbedaan pengertian antara trayek dengan lintasan. Trayek di titik beratkan pada asal dan tujuan, sedangkan lintasan menunjuk pada ruas jalan yang dilalui kendaraan umum yang melayani trayek bersangkutan, lintasan adalah rute. Jadi, satu trayek dapat menawarkan lebih dari satu rute.

\section{Biaya Operasional Kendaraan (BOK)}

Biaya operasi kendaraan adalah semua biaya yang harus dikeluarkan oleh operator sehubungan kepemilikan dan pengoperasian kendaraan untuk tujuan komersial dan pribadi yang terdiri dari biaya tetap dan biaya tidak tetap. Biaya operasi kendaraan total per tahun dihitung dengan rumus berikut:

$\mathrm{BOK}_{\text {Total }} /$ th $=\mathrm{BOK}_{\text {Tetap }} /$ th $+\mathrm{BOK}_{\text {Variabel }}$ /th

\section{Penghematan BOK dan Penghematan BBM}

Nilai manfaat dari perencanaan serta pengembangan angkutan khusus karyawan baru akan terasa manfaatnya jika dapat memberikan dampak bagi pengguna angkutan serta memberikan kontribusi bagi pemerintah berupa penghematan biaya operasional kendaraan (BOK) dan penghematan terhadap konsumsi BBM. Beberapa variabel yang diperlukan untuk menghitung penghematan BOK dan penghematan BBM berdasarkan persepsi penumpang sebagai berikut:

Penghematan $\mathrm{BOK} /$ th $=$ biaya $\mathrm{KP} /$ th - biaya AKK/th

Penghematan $\mathrm{BBBM} / \mathrm{th}=\mathrm{BBBM} \mathrm{KP} / \mathrm{th}-$ BBBM AKK/th

\section{Sistem Operasional Angkutan Khusus Karyawan}

Secara umum, perencanaan sistem operasional pada pelayanan Angkutan khusus karyawan mengacu pada standar indikator kualitas pelayanan angkutan kota berdasarkan sisi pandang pengguna yang ditetapkan oleh Direktorat Jenderal Perhubungan Darat.

1. Perhitungan waktu siklus merupakan waktu yang dibutuhkan untuk melakukan perjalanan pergi pulang pada suatu trayek, dengan memperhatikan waktu henti di terminal dan waktu hambatan di perjalanan, dalam hal ini terjadi deviasi waktu sebesar $5 \%$ dari waktu perjalanan. 
2. Perhitungan frekuensi merupakan jumlah keberangkatan atau kedatangan kendaraan angkutan kota yang melewati dalam satu trayek selama periode waktu tertentu dan pada satu titik tertentu dan pada satu titik tertentu, (Jason, 1982).

3. Perhitungan headway merupakan selisih waktu keberangkatan atau kedatangan antara kendaraan angkutan kota dengan kendaraan angkutan kota dibelakangnya dalam satu trayek pada satu titik tertentu.

4. Untuk menentukan kebutuhan jumlah kendaraan angkutan kota yang tetap sesuai dengan kebutuhan sulit dipastikan, yang dapat dilakukan adalah mendekati besarnya kebutuhan. Jumlah kebutuhan angkutan dipengaruhi oleh beberapa faktor yang meliputi jarak rute, waktu operasi, dan faktor muatan.

\section{METODE PENELITIAN}

Dalam penelitian ini dipilih kawasan pusat Pemerintahan Kota Denpasar di Lumintang sebagai lokasi penelitian karena pada kawasan ini merupakan pusat perkantoran Pemerintah Kota Denpasar. Setiap harinya sebagian besar karyawan menggunakan kendaraan pribadi untuk menuju kawasan ini. Untuk mengatasi hal ini diperlukan suatu alternatif dengan manajaemen lalu lintas yang mengutamakan perpindahan orang bukan kendaraan yaitu dengan penggunaan angkutan khusus karyawan agar penggunaan angkutan pribadi dapat dikurangi.

\section{Studi Literatur, Desain Kuesioner dan Sampel}

Studi literatur pada penelitian ini dilakukan dengan mempelajari referensi-referensi dan peraturan-peraturan pemerintah yang terkait dengan ilmu transportasi khususnya referensireferensi dan peraturan-peraturan pemerintah tentang angkutan khusus karyawan dan juga membaca penelitian-penelitian sebelumnya yang mendukung penelitian ini. Metode penyebaran kuesioner yang digunakan dalam penelitian ini adalah Teknik Stated Preference, dimana sebagai responden adalah karyawan pada pusat pemerintahan Kota Denpasar di Lumintang. Pengambilan sampel pada penelitian ini dilakukan secara acak stratifikasi (stratified random sampling), yaitu pengambilan sampel dari anggota populasi secara acak dan berstrata secara proporsional per SKPD sehingga mampu mewakili populasi yang diharapkan.

\section{Survei Pendahuluan}

Survei pendahuluan (pilot survey) adalah survei skala kecil yang dilakukan sebelum pelaksanaan survei menyeluruh, dimana hasil survei pendahuluan yang dilakukan akan menentukan besarnya jumlah sampel yang nantinya akan digunakan pada survei menyeluruh. Selanjutnya dilakukan penyebaran kuesioner pada 30 responden sebagai sampel awal.

Parameter yang digunakan dalam menentukan jumlah sampel pada penelitian ini adalah jumlah pendapatan keluarga tiap bulan responden. Berdasarkan hasil perhitungan jumlah sampel minimum, maka dalam penelitian ini akan digunakan jumlah sampel sebesar 240 orang, sehingga secara proposional didapat jumlah sampel pada masing-masing lokasi.

\section{Analisis Potensi Penumpang (Demand) dan Rute Layanan}

Potensi penumpang (demand) yang berminat menggunakan angkutan khusus karyawan diperoleh berdasarkan responden/ penumpang (demand) yang berminat menggunakan angkutan khusus karyawan hasil survei Stated Preferance (SP) selanjutnya ditentukan lintasan atau rute layanan angkutan khusus karyawan.

\section{Analisis Sistem Operasional Angkutan Khusus Karyawan}

Jumlah kendaraan per waktu operasi adalah kebutuhan kendaraan yang ditentukan untuk waktu operasi angkutan antar jemput pada masing-masing rute yang ditentukan dengan membagi jumlah penumpang pada masing-masing rute dengan hasil perkalian antara kapasitas kendaraan rencana, faktor muatan dengan lama hari operasi perhari dibagi waktu tempuh dikalikan dengan panjang rute dibagi rata-rata panjang perjalanan penumpang dikalikan faktor koreksi untuk ketepatan data asal tujuan perjalanan. 


\section{Perhitungan Waktu Siklus, Frekwensi dan Headway}

Menganalisis waktu yang dibutuhkan untuk melakukan perjalanan pergi pulang pada suatu trayek, dengan memperhatikan waktu henti di terminal dan waktu hambatan di perjalanan, dalam hal ini terjadi deviasi waktu sebesar 5\% dari waktu perjalanan. Menghitung frekwensi yaitu jumlah keberangkatan atau kedatangan kendaraan angkutan kota yang melewati dalam satu trayek selama periode waktu tertentu dan pada satu titik tertentu dan headway selisih waktu keberangkatan antara kendaraan.

\section{Perhitungan Kebutuhan Armada dan Penjadwalan \\ Menentukan kebutuhan jumlah kendaraan} angkutan kota yang tetap, yang dapat dilakukan adalah mendekati besarnya kebutuhan. Dari analisis penumpang (demand) dan penentuan jumlah kendaraan serta pola pelayanan yang akan dioperasikan, selanjutnya dilakukan pembuatan jadwal bus. Untuk angkutan khusus karyawan penjadwalan kendaraan berdasarkan jam mulai kerja.

\section{Analisis Biaya Operasi Kendaraan}

Biaya operasi kendaraan total per tahun dihitung dengan menjumlahkan biaya operasi kendaraan tetap per tahun ditambah dengan biaya operasi kendaraan tidak tetap (variable) per tahun.

\section{Analisis Penghematan BOK dan Penghematan Konsumsi BBM}

Besarnya penghematan biaya operasi kendaraan (BOK) adalah dengan menghitung besarnya BOK angkutan pribadi dari seluruh karyawan yang bersedia menggunakan angkutan khusus karyawan per tahun dikurangi dengan BOK karyawan yang bersedia menggunakan angkutan khusus karyawan per tahun. Sedangkan dalam menghitung penghematan konsumsi BBM akibat dari pengoperasian angkutan khusus karyawan yaitu dengan menghitung besarnya biaya bahan bakar minyak angkutan pribadi per tahun dikurangi besarnya penggunaan biaya bahan bakar minyak angkutan khusus karyawan per tahun.

\section{HASIL DAN PEMBAHASAN}

Perencanaan rute layanan angkutan khusus karyawan didasarkan atas lokasi kebutuhan demand, berdasarkan hasil survei yang telah dilakukan pada 352 responden yang mewakili 1.129 populasi. Dari hasil survei stated preference diperoleh data responden yang bersedia menggunakan angkutan khusus karyawan sebesar 264 orang atau $75 \%$ dari 352 responden. Selanjutnya data dari hasil survei terhadap karyawan tersebut dipetakan pada peta jaringan jalan Kota Denpasar.

Dari hasil analisis yang telah dilakukan, diperoleh 4 trayek angkutan khusus karyawan yaitu Trayek DU-01 lintasan Lumintang Ubung, Trayek DT-01 lintasan Lumintang Kamboja, Trayek DB-01 lintasan Lumintang Gunung Agung, dan Trayek DS-01 lintasan Lumintang - Renon. Berdasarkan potensi jumlah penumpang pada masing-masing trayek ditetapkan headwaynya 2 menit untuk trayek DU-01 dan headway 10 menit untuk trayek lainnya dengan waktu siklus antara $18 \mathrm{~s} / \mathrm{d} 58$ menit. Jumlah kendaraan yang dibutuhkan untuk pengoperasian angkutan khusus karyawan adalah 22 unit. Jenis armada yang digunakan adalah Isuzu NKR 55 Long Wheel Base dengan 16 tempat duduk tidak termasuk pengemudi. Biaya operasional kendaraan untuk angkutan khusus karyawan setiap harinya pada Trayek DU-01 adalah Rp.252.531, pada Trayek DT-01 sejumlah Rp.258.971, pada Trayek DB01 sebesar Rp.258.166, dan pada Trayek DS-01 adalah Rp.270.241.

Besarnya biaya operasinal angkutan khusus karyawan untuk semua kendaraan sebesar Rp.1.281.593.256 per tahunnya sedangkan biaya yang dikeluarkan untuk pengoperasian kendaraan pribadi per tahunnya sebesar Rp.2.091.925.275, sehingga diperoleh penghematan biaya operasional kendaraan sebesar Rp.810.3320.019. Konsumsi BBM yang diperlukan untuk pengoperasian seluruh kendaraan angkutan khusus karyawan sebanyak 10.536 liter per tahunnya, sedangkan konsumsi BBM yang diperlukan untuk pengoperasian kendaraan pribadi sebanyak 17.160 liter per tahunnya, sehingga diperoleh penghematan bahan bakar sebanyak 6.624 liter per tahunnya. 


\section{SIMPULAN DAN SARAN}

Simpulan

Adapun simpulan dari hasi pembahasan sebagai berikut :

1. Berdasarkan hasil survei dan analisis data, dapat disimpulkan bahwa karakteristik sosial ekonomi karyawan, besarnya bangkitan perjalanan serta potensi penggunaan angkutan khusus karyawan pada pusat Pemerintahan Kota Denpasar di Lumintang adalah sebagai berikut :

a. Sebanyak $17,67 \%$ karyawan memiliki kendaraan roda empat, 55,04\% ratarata karyawan memiliki kendaraan roda dua lebih dari satu, dan 27,29\% karyawan memiliki sepeda.

b. Sebagian besar karyawan menggunakan sepeda motor yaitu sebesar $84,44 \%$ untuk menuju ke kantor saat ini, kemudian 11,94 \% karyawan menggunakan mobil, 2,78\% karyawan diantar, 0,56\% karyawan menggunakan kendaraan umum serta $0,28 \%$ menggunakan kendaraan lainnya.

c. Biaya transportasi keluarga per bulan yang memiliki prosentase paling tinggi adalah $26,99 \%$ yaitu antara $\mathrm{Rp}$. 350.000 - Rp. 500.000 dan prosentase pengeluaran biaya transportasi keluarga per bulan yang paling rendah adalah 9,09\% yaitu kurang dari Rp. 150.000.

d. Prosentase pendapatan karyawan paling tinggi adalah $31,82 \%$ karyawan yang memiliki pendapatan antara Rp. $3.000 .000-5.000 .000$, kemudian $30,40 \%$ karyawan memiliki pendapatan antara Rp. 2.000.000 - 3.000.000, 20,74\% karyawan memiliki pendapatan antara Rp. 5.000.000 - 10.000.000, $13,92 \%$ karyawan memiliki pendapatan kurang dari Rp. 2.000.000 dan yang terakhir $3,13 \%$ karyawan memiliki pendapatan lebih dari Rp. 10.000.000.

e. Jarak perjalanan dari rumah ke kantor yang memiliki prosentase paling tinggi adalah $50,85 \%$ yaitu antara $0-5 \mathrm{~km}$, $27,56 \%$ yaitu antara $6-10 \mathrm{~km}, 10,51 \%$ antara $11-15 \mathrm{~km}, 3,69 \%$ antara $16-20$ $\mathrm{km}, 3,41 \%$ antara $21-25 \mathrm{~km}$, dan prosentase jarak perjalanan dari rumah ke kantor yang paling rendah adalah $1,99 \%$ yaitu antara $26-30 \mathrm{~km}$ dan lebih besar dari $30 \mathrm{~km}$. f. Waktu tempuh perjalanan dari rumah ke kantor yang memiliki prosentase paling tinggi adalah $47,76 \%$ yaitu antara $11-20$ menit, $31,53 \%$ yaitu antara 21-30 menit, $13,35 \%$ yaitu antara 0-10 menit, 5,97\% yaitu antara 41-50 menit dan prosentase waktu tempuh perjalanan dari rumah ke kantor yang paling rendah adalah $3,69 \%$ yaitu antara $31-40 \mathrm{~km}$ dan lebih besar dari 50 menit.

g. Dari 352 sampel yang diambil, sebanyak $75 \%$ (264 orang) responden berminat untuk beralih dari kendaraan yang digunakan saat ini menggunakan angkutan khusus karyawan dan 25\% (88 orang) responden tidak bersedia beralih menggunakan angkutan khusus karyawan.

h. Penyebaran alamat karyawan yang memiliki prosentase paling besar adalah di Denpasar Utara sebesar 32,95 $\%$, kemudian luar Denpasar sebesar 26,14\%, Denpasar Timur sebesar 17,42\%, Denpasar Barat sebesar 12,50 \% dan Denpasar Selatan sebesar 10,98 $\%$.

i. Berdasarkan fasilitas yang diinginkan yaitu sebagian besar mengharapkan kendaraan dilengkapi fasilitas AC yaitu sejumlah 256 orang $(96,97 \%)$ sedangkan dengan kendaraan tanpa $\mathrm{AC}$ sejumlah 8 orang $(3,03 \%)$. Kemudian jenis kendaraan yang diharapkan oleh responden yang bersedia beralih menggunakan angkutan khusus karyawan yaitu sebanyak $213(80,68 \%)$ orang menginginkan menggunakan kendaraan minibus dan 51 (19,32\%) orang menginginkan menggunakan bus kecil.

j. Dari 352 responden sebanyak 60,31\% responden bersedia dilakukan pengaturan jam kerja per SKPD dan $39,69 \%$ responden tidak bersedia dilakukan pengaturan jam kerja per SKPD.

k. Pola layanan yang diinginkan adalah antar jemput di jalan utama pada alamat masing-masing.

1. Berdasarkan hasil survei yang dilakukan, dapat diketahui bahwa $73,47 \%$ responden melakukan perjalanan keluar kantor dalam sehari antara $1-2$ kali, $11,73 \%$ responden 
tidak tentu melakukan perjalanan keluar kantor dalam sehari, 9,69\% responden melakukan perjalanan keluar kantor dalam sehari antara 3-4 kali dan $5,10 \%$ responden melakukan perjalanan keluar kantor dalam sehari lebih dari 4 kali.

m. Dari hasil survei yang dilakukan, dapat diketahui bahwa $59,84 \%$ responden melakukan perjalanan keluar kantor untuk keperluan kantor (seperti rapat dan lain-lain), $22,83 \%$ responden melakukan perjalanan keluar kantor untuk keperluan makan siang, dan $8,66 \%$ responden melakukan perjalanan keluar untuk keperluan antar jemput anak dan keperluan lainnya.

n. Besarnya bangkitan perjalanan yang akan ditimbulkan oleh pusat Pemerintahan Kota Denpasar di Lumintang sebanyak 1.129 orang.

2. Berdasarkan analisis yang telah dilakukan, dapat disimpulkan bahwa sistem operasional angkutan khusus karyawan yang dapat diterapkan pada pusat pemerintahan Kota Denpasar di Lumintang adalah sebagai berikut :

a. Dari hasil analisis yang telah dilakukan, diperoleh 4 trayek angkutan khusus karyawan yaitu Trayek DU-01 lintasan Lumintang-Ubung, Trayek DT-01 lintasan Lumintang-Kamboja, Trayek DB-01 lintasan LumintangGunung Agung, dan Trayek DS-01 lintasan Lumintang- Renon. Jenis armada yang digunakan adalah Isuzu NKR 55 Long Wheel Base dengan 16 tempat duduk tidak termasuk pengemudi. Berdasarkan potensi jumlah penumpang pada masingmasing trayek ditetapkan headwaynya 2 menit untuk trayek DU-01, 10 menit untuk trayek DT-01 dan DB-01, serta 5 menit untuk trayek DS-01, waktu siklusnya antara $23 \mathrm{~s} / \mathrm{d} 58$ menit.

b. Pelayanan angkutan khusus karyawan ini dikhususkan untuk karyawan yang bekerja pada pusat Pemerintahan Kota Denpasar di Lumintang. Waktu pelayanan didesain selama $11 \mathrm{jam} / \mathrm{hari}$ yang terbagi dalam 3 shift. Shift I beroperasi mulai pukul $06.00 \mathrm{~s} / \mathrm{d} 07.30$ dilanjutkan dengan shift II yang beroperasi mulai pukul $15.30 \mathrm{~s} / \mathrm{d} 17.00$ dan shift III beroperasi sesuai dengan kebutuhan kegiatan keluar kantor yang dilakukan karyawan.

3. Besarnya biaya operasional kendaraan total untuk pengoperasian angkutan khusus karyawan pada pusat Pemerintahan Kota Denpasar di Lumintang adalah Rp.60.607.625 /th untuk trayek DU-01, Rp.62.153.241 /th untuk trayek DT-01, Rp.61.960.039/th untuk trayek DB-01, dan Rp. 64.858.068/th untuk trayek DS-01.

4. Total biaya yang dikeluarkan untuk pengoperasian seluruh angkutan khusus karyawan sebesar Rp.1.281.593.256, sedangkan total biaya yang dikeluarkan untuk penggunaan kendaraan pribadi dari 264 karyawan sebesar Rp. 2.091.925.275. Dari data tersebut diatas, diperoleh besarnya penghematan biaya operasional kendaraan dari pengoperasian angkutan khusus karyawan sebesar Rp. 810.332.019 per tahun. Penghematan konsumsi BBM dengan dioperasikannya angkuan khusus karyawan sebesar 6,624 liter per tahunnya.

\section{Saran}

Adapun saran yang bisa disampaikan dalam penelitian ini antara lain :

a. Berdasarkan hasil penelitian terdapat $25 \%$ karyawan yang tidak bersedia menggunakan angkutan khusus karyawan, sehingga untuk memaksimalkan demand yang akan menggunakan angkutan, diperlukan campur tangan pemerintah untuk menetapkan kebijakan dan sangsi bagi karyawan agar seluruh karyawan wajib menggunakan angkutan khusus karyawan.

b. Berdasarkan hasil penelitian terdapat $22,83 \%$ karyawan melakukan perjalanan keluar kantor untuk keperluan makan siang, sehingga disarankan pemerintah menyediakan fasilitas kantin yang memadai untuk masing-masing SKPD.

c. Waktu pelayanan angkutan khusus karyawan terbagi menjadi dua shift yaitu pagi $06.00 \mathrm{~s} / \mathrm{d} 07.30$ dan sore hari $15.30 \mathrm{~s} / \mathrm{d}$ 17.00, sehingga ada waktu kosong dimana angkutan khusus karyawan tidak beroperasi. Berdasarkan hal tersebut disarankan untuk memanfaatkan kendaraan untuk digunakan sebagai kendaraan dinas karyawan. 
d. Waktu dimulainya jam kantor dan jam pulang kerja pada masing-masing SKPD secara umum pada waktu yang bersamaan, sehingga terjadi penumpukan demand secara bersamaan untuk itu disarankan agar pemerintah mengatur pemisahan jam kerja masing-masing SKPD (stagerring work hour).

\section{DAFTAR PUSTAKA}

Ariyasa, P.A. 2013. Analisis Kinerja Simpang dan Pembebanan Ruas Jlaan pada Pengelolaan Lalu Lintas dengan Sistem Satu Arah (Studi Kasus Simpang Jalan Gatot Subroto - Jalan Ahmad Yani). Denpasar: Jurusan Teknik Sipil Fakultas Teknik Universitas Udayana.

Departemen Perhubungan. 2002. Pedoman Teknis Penyelenggaraan Angkutan Penumpang Umum di Wilayah Perkotaan dalam Trayek dan Teratur, Jakarta: Direktorat Jenderal Perhubungan Darat.

Departemen Perhubungan. 2003. Keputusan Mentri Perhubungan Nomor KM. 35 Tahun 2003 tentang Penyelenggaraan angkutan Orang di Jalan dengan Kendaraan Umum. Jakarta: Direktorat Jenderal Perhubungan Darat.

Departemen Perhubungan. 1993. Peraturan Pemerintah No. 41 Tahun1993 tentang Angkutan Jalan. Jakarta: Direktorat Jenderal Perhubungan Darat.

Departemen Perhubungan. 1996. Penentuan Jumlah Armada dan Penjadwalan. Jakarta: Badan Pendidikan dan Latihan Perhubungan Pusat Pendidikan dan Latihan Perhubungan Darat.

FSTPT - ITB. 1999. Studi Evaluasi Tarif Angkutan Umum dan Analisis Ability to Pay (ATP) dan Willingness to Pay (WTP) di DKI Jakarta. Bandung : Kelompok Bidang Keahlian Rekayasa Transportasi Jurusan Teknik Sipil.

Igbal, H. M. 2002. Pokok - Pokok Materi Statistik 2. Jakarta: PT. Bumi Aksara.

LPM - ITB. 1997. Studi Kelayakan Proyek Transportasi. Bandung: Lembaga Pengabdian Masyarakat ITB bekerjasama dengan Kelompok Bidang Keahlian Rekayasa Transportasi Jurusan Teknik Sipil ITB.

Ortuzar, J.D. 1994. Modeling Transport. England: John Wiley \& Sons, Chichester.
Parikesit, D. 1993. Kemungkinan Penggunaan Stated Preferrence dalam Perencanaan Angkutan Umum. Yogyakarta: Jurusan Teknik Sipil Fakultas Teknik UGM.

Pearmain, D. 1990. Stated Preference Technigues. Belanda: A. Guide to Practice. Hague Consultancy Group, Den Haag.

Pradnyana, D.K.A. 2011. Analisis Pengoperasian Angkutan Kota Anak Sekolah di Kota Denpasar (Studi Kasus: Kawasan Pendidikan Jalan Kamboja). Denpasar: Program Magister Program Studi Teknik Sipil Program Pascasarjana Universitas Udayana.

Santoso, I. 1996. Perencanaan Prasarana Angkutan Umum. Bandung: Pusat Transportasi dan Komuniaksi. Institut Teknologi Bandung.

Sriastuti, D.A.N. 2010. Analisis Kelayakan Finansial Pengoperasian Angkutan Antar Jemput Siswa Sekolah pada Koridor Jalan Gunung Agung Denpasar. Denpasar: Program Magister Program Studi Teknik Sipil Program Pascasarjana Universitas Udayana.

Supoyo. 2004. Prospek Angkutan Antar Jemput Bis Karyawan Studi Kasus Kantor Pemerintah Propinsi Jawa Tengah. Semarang: Program Pascasarjana Magister Teknik Sipil Universitas Diponegoro.

Sudjana, 1996. Metode Statistika. Bandung: Penerbit Tarsitu Bandung.

Tamin, O.Z. 2000. Perencanaan dan Pemodelan Transportasi. Bandung: Penerbit ITB.

Warpani S.P. 2002. Pengelolaan Lalu Lintas dan Angkutan Jalan. Bandung: Penerbit ITB. 